\title{
TINDAKAN KHUSUS BERUPA PEMBAKARAN DAN/ATAU PENENGGELAMAN KAPAL IKAN ASING YANG MELAKUKAN TINDAK PIDANA PERIKANAN DI ZONA EKONOMI EKSKLUSIF INDONESIA
}

\author{
Mangisi Simanjuntak \\ Email: ysahala@ymail.com \\ Universitas Kristen \\ Indonesia, Jakarta, Indonesia
}

\begin{abstract}
In the research shows that the rampant illegal fishing causes Indonesia to lose its fish resources around Rp 30 trillion per year. Fishing vessels caught for committing a criminal offense are processed under applicable law. The legal process took so long that many fishing vessels that were moored at the base were damaged while the finished ones and the ship's court had been auctioned off but in reality the fishing vessel was back to its owner.For the settlement of both the necessary special measures of burning and / or drowning with sufficient preliminary evidence and approval of the chairman of the district court as stated in Article 69 paragraph (1), (4) and Article 76A of Law Number 45 Year 2009 concerning Fisheries. Countries whose fishing boats conduct illegal fishing protest against such special measures and how prevention efforts for fishery crimes can be minimized? Specific acts for fishery crimes committed in ZEE Indonesia shall not be made as they are contrary to Article 73 paragraph (2), Article 194, Article 309 of the UN Convention 1982 (Unclos 1982) and Article 15 of Law Number 5 Year 1983 on ZEE Indonesia And Article 104 Paragraph (1) of Law Number 31 Year 2004 concerning Fisheries that permit fishing vessels to be exempted by a ransom of adequate security deposit, by way of a court application. Such application shall be filed by the ship's captain and / or his or her representative. If the court rejects the aforementioned redemption application then the legal proceedings will continue and if the ship is not redeemed, the legal proceedings continue and there should also be a statement signed by the ship's captain or the representative of his country stating that his fishing vessel will not be redeemed. Burning and / or The drowning of foreign fishing vessels committing fishery crimes in ZEE Indonesia can only be done if the case has a permanent legal force. To engage in the burning and/or drowning of foreign fishing vessels committing a fishery crime in ZEE Indonesia requires a new legal norm as described above.
\end{abstract}

Keywords: Special Measures of Combustion and/or Drowning of Foreign Fishing Vessels

\section{Pendahuluan}

Kekayaan laut Indonesia terutama di bidang perikanan tentunya dapat meningkatkan pembangunan nasional yang adil dan merata. Usaha- usaha pencegahan dan peniadaan kerugian negara termasuk kerugian dari sektor hasil laut berupa tindak pidana perikanan khususnya di ZEE Indonesia

\footnotetext{
${ }^{1}$ Dosen tidak tetap Fakultas Hukum Universitas Kristen Indonesia/ Perwira Hukum TNI Angkatan Laut.
}

yang dilakukan oleh kapal-kapal ikan asing (KIA), secara terus menerus perlu ditingkatkan. Tindak Pidana Perikanan oleh KIA sering kali terjadi, akibat perbuatan ini ditaksir Indonesia mengalami kerugian hampir Rp 30 trilyun (tiga puluh trilyun). Indonesia saat ini baru dapat memanfaatkan potensi perikanannya sekitar 225 triliun atau sekitar 7,5\% saja baik di ZEE Indonesia maupun Laut Teritorial. ${ }^{2}$

\footnotetext{
${ }^{2}$ Dikdik Mohammad Sodik, Hukum Laut Internasional dan Pengaturannya di Indonesia, Bandung: Refika 2011, hal 77.
} 
Tindak pidana perikanan merupakan tindak pidana yang merugikan negara dan merusak mata pencarian nelayan. Negara dan aparat penegak hukum harus memberantas penangkapan ikan illegal demi kewibawaan negara dan kesejaterahan masyarakat khususnya nelayan. Penegakan hukum terhadap kapal ikan asing illegal selama ini berjalan lambat dan bahkan dapat dikatakan tidak efektif, hal ini dapat dilihat dari semakin seringnya terjadi penangkapan ikan illegal di wilayah perairan yang sama bahkan oleh kapal ikan asing yang sama.

Pemerintah Indonesia melalui Kementerian Kelautan dan Perikanan (KKP), 2 (dua) tahun terakhir ini, melakukan tindakan khusus berupa pembakaran dan/atau penenggelaman kapal ikan asing illegal yang melakukan tindak pidana perikanan di Wilayah Pengelolaan Perikanan Indonesia (WPPI), tindakan khusus tersebut dilakukan karena adanya pasal 69 ayat(4) dan Pasal 76A Undang-Undang Nomor 45 Tahun 2009 tentang Perubahan Undang-Undang Nomor 31 Tahun 2004 tentang Perikanan.

Pasal 69 ayat (1) dan (4) serta pasal 76A UndangUndang Nomor 45 Tahun 2009 yang dipakai sebagai dasar hukum tindakan khusus tersebut menyatakan:

(1) Kapal pengawas perikanan berfungsi melaksanakan pengawasan dan penegakan hukum di bidang perikanan dalam wilayah pengelolaan perikanan Negara Republik Indonesia.

(4) Dalam melaksanakan fungsi sebagaimana dimaksud pada ayat (1) penyidik dan/atau pengawas perikanan dapat melakukan tindakan khusus berupa pembakaran dan/atau penenggelaman kapal perikanan yang berbendera asing berdasarkan bukti permulaan yang cukup. ${ }^{3}$

Pasal 76A Undang-Undang Nomor 45 Tahun 2009 menyatakan:

Benda dan/atau alat yang digunakan dalam dan/ atau yang dihasilkan dari tindak pidana perikanan dapat dirampas untuk negara atau dimusnahkan setelah mendapat persetujuan ketua pengadilan negeri.

Menyikapi pasal 76A tersebut, MA mengeluarkan Surat Edaran Nomor 1 Tahun 2015 Tentang Barang Bukti Kapal Dalam Perkara Pidana Perikanan, maka tentang pemusnahan kapal ditentukan sebagai berikut:

${ }^{3}$ Gatot Supramono, Hukum Acara Pidana dan Hukum Pidana di Bidang Perikanan, Jakarta: PT Rineke Cipta, hal 307.
1. Bahwa terhadap Pasal 69 ayat (4) dalam melaksanakan fungsi sebagaimana dimaksud pada ayat (1) penyidik dan/atau pengawas pemeriksa dapat melakukan tindakan khusus berupa pembakaran dan/atau penenggelaman kapal perikanan yang berbendera asing berdasarkan bukti permulaan yang cukup, Terhadap penggunaan Pasal 69 ayat (4) ini, Ketua Pengadilan Negeri tidak mempunyai kewenangan untuk memberikan kewenangan.

2. Bahwa kapal yang terlibat kejahatan pencurian ikan di laut yang telah disita oleh penyidik secara sah menurut hukum dan dijadikan barang bukti maka apabila hendak dimusnahkan atau dilelang, penyidik harus meminta persetujuan Ketua Pengadilan Negeri setempat. Pasal 76A UndangUndang Republik Indonesia Nomor 45 Tahun 2009 tentang Perubahan atas Undang-Undang RI Nomor 31 Tahun 2004 tentang Perikanan jo. Pasal 38, Pasal 45 Undang-Undang Nomor 8 Tahun 1981 tentang KUHAP.

3. Apabila perkara telah dilimpahkan ke Pengadilan Tingkat Pertama, Banding dan Kasasi maka persetujuan pemusnahan diterbitkan oleh Ketua yang bersangkutan, namun apabila perkara telah dilimpahkan kepada majelis, maka persetujuan pemusnahan diterbitkan oleh Majelis Hakim yang bersangkutan.

Pembakaran dan/atau penenggelaman kapal ikan asing tidak boleh dilakukan berdasarkan Pasal 69 ayat (4) yaitu hanya berdasarkan bukti permulaan yang cukup dan Pasal 76A hanya berdasarkan penetapan pengadilan saja karena belum mendapatkan putusan pengadilan yang berkekuatan hukum yang tetap (Inkracht van Gewijs.d.e) dan juga tanpa melihat tempat dilakukan tindak pidana (locus delicti) penangkapan ikan illegal (illegal fishing) tersebut dilakukan, termasuk di ZEE Indonesia. Locus delicti yang dimaksud adalah wilayah pengelolaan perikanan yang meliputi perairan Indonesia, ZEE Indonesia dan sungai, danau, waduk, rawa.

Khusus untuk tindak pidana perikanan yang dilakukan di ZEE Indonesia, pembakaran dan/atau penenggelaman KIA tidak dapat dilakukan begitu saja karena rezim zona ekonomi eksklusif berbeda dengan laut territorial dan mempunyai pengaturan khusus yang diatur dalam pasal 73 ayat (2) Unclos 1982 yang menyatakan:

"Arrested vessel and their crews shall be promptly released upon the posting of reasonable bond or other security (Kapal-kapal yang ditangkap dan 
awak kapalnya harus segera dibebaskan setelah diberikan uang jaminan yang layak atau bentuk jaminan lainnya).

Pasal 73 ayat (2) tersebut sudah dijabarkan dalam hukum nasional yaitu Undang-Undang Nomor 5 Tahun 1983 tentang ZEE Indonesia, pasal 15 ayat (1) Undang-Undang Nomor 5 Tahun 1983 menyatakan permohonan untuk membebaskan kapal dan/atau orang-orang yang ditangkap karena diduga melakukan pelanggaran, sesuai praktek yang berlaku, dapat diajukan oleh perwakilan negara dari kapal asing yang bersangkutan, pemilik, nahkoda atau siapa saja menurut bukti-bukti yang sah mempunyai hubungan kerja atau hubungan usaha dengan kapal tersebut. Pasal 15 ayat (2) nya menyatakan bahwa permohonan pembebasan sebagaimana dimaksud dalam ayat (1), dapat dikabulkan jika pemohon sudah menyerahkan sejumlah uang jaminan yang layak, yang penetapannya dilakukan oleh pengadilan yang berwenang. Dijabarkan juga pada pasal 104 Ayat (1) Undang-Undang Nomor 31 Tahun 2004 Tentang Perikanan. Mengapa negara-negara yang kapal ikannya melakukan illegal fishing menentang pembakaran dan/atau penenggelaman kapal ikan asing yang melakukan tindak pidana perikanan di Zona Ekonomi Eksklusif Indonesia. Bagaimana Norma Hukum baru agar pembakaran dan penenggelaman kapal ikan asing yang melakukan tindak pidana di ZEE Indonesia tidak menimbulkan protes atau gugatan dari negara lain. Untuk mengetahui dan menjelaskan mengapa negara-negara yang kapal ikannya melakukan illegal fishing menentang tindakan khusus berupa pembakaran dan/atau penenggelaman kapal ikan asing yang melakukan tindak pidana perikanan di ZEE Indonesia. Untuk mengetahui dan menjelaskan Bagaimana Norma Hukum baru agar pembakaran dan penenggelaman kapal ikan asing yang melakukan tindak pidana di ZEE Indonesia tidak menimbulkan protes atau gugatan dari negara lain.

\section{Pembahasan}

\section{Alasan Negara-negara yang Melakukan Illegal Fishing Menentang Pembakaran dan/Atau Penenggelaman Kapal Perikanan Berbedera Asing yang Melakukan Tindak Pidana Perikanan di ZEE Indonesia.}

Pembakaran dan/atau penenggelaman terhadap kapal ikan asing yang melakukan tindak pidana perikanan di ZEE Indonesia sebagaimana diatur dalam pasal 69 ayat (1), (4) dan pasal 76A UndangUndang Nomor 45 Tahun 2009 tentang Perikanan tidak boleh dilaksanakan karena:

1. Bertentangan Dengan Pasal 73 Ayat (2) Konvensi PBB Tahun 1982 Tentang Hukum Laut (Unclos 1982).

Berdasarkan Konvensi PBB tentang Hukum Laut Tahun 1982 pada pasal 73 ayat (2) telah jelas dinyatakan 'Arrested vessel and their crews shall be promptly released upon trhe posting of reasonable bond or othe security: bahwa kapal-kapal yang ditangkap dan awak kapalnya harus segera dibebaskan setelah diberikan suatu uang jaminan yang layak atau bentuk jaminan lainnya. ${ }^{4}$

Seharusnya pembakaran dan/atau penenggelaman itu tidak boleh dilakukan karena Pasal 69 ayat (1), ((4) dan pasal 76A Undang-Undang Nomor 45 Tahun 2009 tentang Perikanan tersebut di atas bertentangan dengan Pasal 73 ayat (2) Konvensi Hukum Laut PBB Tahun 1982.

Ketentuan Pasal 73 ayat (2) ini lebih lanjut diteguhkan oleh Pasal 292 ayat (1), yang memberikan yuris.d.iksi kepada Pengadilan Internasional Hukum Laut (International Tribunal Law Of The Seal ITLOS) untuk menangani pengajuan permintaan pembebasan kapal dan nahkoda kapal dengan segera dipelabuhan Negara lain di mana perkara tersebut dapat diproses lebih lanjut. ${ }^{5}$

Pasal 292 Ayat (1) Konvensi Hukum Laut 1982 menyatakan:

"Dalam hal pejabat suatu Negara peserta telah melakukan penahanan kendaraan air yang mengibarkan bendera Negara peserta lain dan dituduhkan bahwa negara yang menahan itu tidak memenuhi ketentuan-ketentuan konvensi ini untuk segera membebaskan kendaraan air atau awaknya setelah penitipan sejumlah uang jaminan atau jaminankeuangan lainnya, maka masalah pembebasan dari penahanan dapat diserahkan

\footnotetext{
${ }^{4}$ Pasal 73 ayat (2) Konvensi Perserikatan Bangsa Bangsa Tahun 1982.

${ }^{5}$ Didik Mohammad Sodik, Op. Cit. hal 91.
} 
kepada pengadilan atau mahkamah manapun yang disepakati oleh para pihak atau, dalam hal tidak tercapainya kesepakatan demikian dalam waktu 10 hari sejak waktu penahanan berdasarkan pasal 287 atau Mahkamah Internasional Hukum Laut."

Penerapan ketentuan pasal 73 Ayat (2) ini dapat dilihat dalam putusan Pengadilan Internasional Hukum Laut dalam kasus Monte Confurco, pada bulan September 2000, kapal penangkap ikan Monte Confurco yang berbendera Sycheles ditangkap dan ditahan oleh kapal pengawas Floreal Perancis. Kapal tersebut dituduh telah melakukan penangkapan ikan secara illegal di zona ekonomi ekskusif Pulau Kreugelen di Perancis bagian selatan dan wilayah Antartika. Negara Sycheles mengajukan permintaan pembebasan dengan segera terhadap kapalnya yang ditahan kepada Pengadilan Internasional Hukum Laut berdasarkan pasal 73 ayat (2) dan pasal 292 ayat

(1) Konvensi PBB Tahun 1982. Berdasarkan faktafakta dan sejumlah jaminan uang yang layak dan sudah dipenuhi serta berdasarkan pasal 292 ayat (1) Konvensi PBB Tentang Hukum Laut .

2. Bertentangan dengan Pasal 194 Konvensi PBB Tentang Hukum Laut Tahun 1982 (Unclos 1982) Perihal Tindakan-Tindakan untuk Mencegah, Mengurangi dan Mengendalikan Pencemaran Lingkungan Laut

Dinyatakan dalam Pasal 194 Konvensi PBB tentang Hukum Laut Tahun 1982 (Unclos 1982) bahwa:

a. Negara-negara harus mengambil segala tindakan yang perlu sesuai dengan konvensi, baik secara individual maupun secara bersama-sama menurut keperluan untuk mencegah, mengurangi dan mengendalikan pencemaran lingkungan laut yang disebabkan oleh setiap sumber dengan menggunakan, untuk keperluan ini cara-cara yang praktis yang ada pada mereka dengan kemampuan mereka.

b. Negara-negara yang harus mengambil segala tindakan yang perlu untuk menjamin agar kegiatan-kegiatan yang berada di bawah yuris.d.iksi atau pengawasan mereka dilakukan

dengan cara sedemikian rupa supaya tindakantindakan dan kegiatan di bawah yuris.d.iksi atau pengawasan mereka tidak menyebar melampaui daerah-daerah yang ada di bawah pelaksanaan hak-hak kedaulatan mereka sesuai dengan konvensi.

c. Tindakan-tindakan yang diambil berdasarkan bab ini harus meliputi segala sumber pencemaran lingkungan laut. ${ }^{6}$

Menurut pasal 67 Undang-Undang Nomor 32 Tahun 2009 tentang Lingkungan Hidup, setiap orang berkewajiban memelihara kelestarian fungsi lingkungan hidup serta mengendalikan pencemaran dan/atau kerusakan lingkungan hidup. ${ }^{7}$ Dari ketentuan pasal 67 tersebut di atas dapat diartikan bahwa pemerintah dan masyarakat seharusnya bekerjasama mencegah terjadinya pencemaran lingkungan hidup termasuk di dalamnya lingkungan laut, apabila sudah terjadi pencemaran pemerintah dengan masyarakat bekerjasama mengambil tindakan untuk menanganinya. Kerjasama yang dimaksud adalah apabila instansi tertentu akan melakukan kegiatan yang dapat berdampak kepada lingkungan hidup (laut), sudah seharusnyalah instansi yang akan meledakan kapal tersebut berkoordinasi terlebih dahulu dengan Kementerian Lingkungan Hidup dan Kehutanan.

3. Bertentangan dengan Pasal 309 Konvensi PBB Tentang Hukum Laut 1982 (Unclos 1982) perihal Persyaratan dan Pengecualian (Reservation And Eexception)

Dinyatakan: "No reservation and exception may be to this Convention unless expressly permnitted by other articles of this Convention" (Tidak ada persyaratan/ reservasi atau pengecualian yang dapat diajukan terhadap Konvensi ini kecuali secara tegas diizinkan oleh pasal-pasal lain Konvensi ini). ${ }^{8}$

Dasar hukum yang digunakan dalam pembakaran dan/atau penenggelaman kapal ikan asing yang melakukan tindak pidana perikanan di ZEE Indonesia adalah pasal 69 ayat (1), (4) dan pasal 76A UndangUndang Nomor 45 Tahun 2009 tentang Perikanan juga adanya penetapan persetujuan Ketua Pengadilan. Pasal 69 ayat (1), (4) dan pasal 76A Undang- Undang Nomor 45 Tahun 2009 tentang Perikanan ini seharusnya tidak boleh ada karena selain bertentangan dengan pasal 73 ayat (2) juga tidak dibolehkan oleh pasal 309 Konvensi PBB tentang Hukum LautTahun 1982, karena sebagai negara yang meratifikasi Unclos

\footnotetext{
${ }^{6}$ Pasal 194 Konvensi Hukum Laut PBB Tahun 1982.

${ }^{7}$ Pasal 67 Undang-Undang Nomor 32 Tahun 20090 tentang Perlindungan dan Pengelolaan Lingkungan Hidup.

${ }^{8}$ Huala Adolf, Aspek-Aspek Negara Dalam Hukum Internasional. Jakarta: PT RajaGrtafindo Persada, 2002), hal 301.
} 
1982, semua peraturan Indonesia yang berhubungan dengan laut harus sesuai dengan pasal-pasal yang ada dalam Konvensi PBB tentang Hukum Laut Tahun 1982, kecuali secara tegas diizinkan oleh pasal-pasal lain Konvensi ini.

Apabila Indonesia telah meratifikasi Konvensi PBB tentang Hukum Laut Tahun 1982 dengan Undang-Undang Nomor 17 Tahun 1985, berarti Indonesia telah menyepakati semua isinya yang dituangkan dalam pasal-pasal, sehingga kita berkewajiban menuangkan dalam peraturan dan perundang-undangan nasional. Sebagai pihak yang paling bertanggung jawab, maka sudah semestinya pemerintah melakukan pengawasan dan pengelolaan secara serius, baik dengan cara membuat undangundang yang jelas dan menegakkannya dengan sungguh-sungguh.. Konvensi PBB tentang Hukum Laut Tahun 1982 merupakan kaidah hukum internasional.

Negara Indonesia sudah meratifikasi Unclos 1982 dengan Undang-Undang Nomor 17 Tahun 1985. Ratifikasi yang dilakukan Indonesia tersebut tanpa reservasi (pengecualian), artinya semua pasal yang terdapat dalam Unclos 1982 harus diterima seutuhnya oleh negara-negara yang meratifikasi. Tidak boleh ada pasal yang dirubah atau tidak dimasukkan dalam undang-undang Indonesia. Reservasi atau pengecualian merupakan pencerminan dari perubahan atau amandemen yang disisipkan pada suatu perjanjian oleh suatu pihak sebagai suatu persyaratan tertentu atau tidak langsung untuk melakukan ratifikasi. Suatu reservasi harus diterima oleh pihak-pihak hanya jika perjanjian itu mulai berlaku dan mempunyai akibat hukum.

Pada prinsipnya Konvensi PBB Tahun 1982 tentang Hukum Laut merupakan suatu konvensi yang harus diterima secara utuh, kalau suatu negara tidak bisa menerima secara utuh maka tidak boleh menerimanya sebagian saja (parsial). Suatu negara pantai tidak perlu membuat suatu undang-undang nasional yang tidak sesuai dengan ketentuanketentuan yang sudah diatur dalam Unclos 1982 kalau hanya menerima sebagian dari pasal-pasal dalam Unclos 1982 tersebut, apalagi kalau ada ketentuan dalam klausul undang-undang nasional Negara pantai tersebut bertentangan dengan Unclos 1982, negara pantai harus menerima semua pasalpasal yang terdapat dalam Unclos 1982. Apabila Indonesia sebagai negara pantai yang memiliki zona ekonomi eksklusif membuat undang-undang nasional yang baru tentang ZEE Indonesia yang beberapa pasalnya bertentangan dengan Unclos 1982, maka undang-undang tersebut tidak efektif dan tidak bisa diberlakukan secara internasional.

4. Bertentangan Dengan Pasal 15 Undang-Undang Nomor 5 Tahun 1983 Tentang .Zona Ekonomi Eksklusif Indonesia.

Tindakan khusus berupa pembakaran dan/atau penenggelaman kapal ikan asing yang melakukan tindak pidana perikanan di ZEE Indonesia adalah bertentangan dengan Pasal 15 dan penjelasannya Undang-Undang Nomor 5 Tahun 1983 tentang Zona Ekonomi Eksklusif Indonesia. Berdasarkan pasal 15 dan penjelasannya tersebut dinyatakan bahwa:

1) Permohonan untuk membebaskan kapal dan/ atau orang-orang yang ditangkap karena didakwa melakukan pelanggaran terhadap undang-undang ini atau peraturan perundang-undangan yang dikeluarkanberdasarkanundang-undangini, dapat dilakukan setiap waktu sebelum ada keputusan dari pengadilan negeri yang berwenang.

2) Permohonan untuk membebaskan sebagaimana dimaksud dalam ayat (1), dapat dikabulkan jika pemohon sudah menyerahkan sejumlah jaminan yang layak, yang penetapannya dilakukan oleh pengadilan negeri yang berwenang.

3) Penjelasan atas Pasal 15 tersebut adalah permohonan untuk membebaskan kapal dan/atau orangorang yang ditangkap karena diduga melakukan pelanggaran, sesuai dengan praktek yang berlaku, dapat diajukan oleh perwakilan Negara dari kapal ikan asing yang bersangkutan, pemilik, nahkoda atau siapa saja menurut bukti-bukti yang syah mempunyai hubungan kerja atau hubungan usaha dengn kapal tersebut. Penetapan besarnya uang jaminan ditentukan berdasarkan harga kapal, alatalat perlengkapan dan hasil dari kegiatannya ditambah besarnya jumlah denda maksimum.

Sesuai pasal 15 dan penjelasannya tersebut, seharusrnya dalam penyelasaian perkara tindak pidana perikanan yang terjadi di ZEE Indonesia oleh kapal-kapal ikan asing, nakhoda/ pemilik kapal atau perwakilan Negara kapal dapat saja menebus kapal ikannya dan langsung membawa kapal ikannya ke negaranya atau dapat juga kapal ikannya tidak mau atau tidak mampu untuk ditebus. Oleh karena itu, dapat dimungkinkan kapal ikan asing tersebut ditebus atau tidak ditebus oleh nakhoda/ pemilik kapal atau perwakilan Negara kapal.

Dari ketentuan dan penjelasan ayat (1) dan (2) tersebut di atas dapat disimpulkan bahwa kapal 
dan/atau orang yang melakukan pelanggaran di ZEE Indonesia dapat dibebaskan, nahkoda dan kapalnya langsung pulang ke negaranya dengan jaminan sejumlah uang sebelum ada keputusan dari pengadilan. Apabila si terdakwa dapat bebas dan langsung pulang ke negaranya, hal ini mengakibatkan pemeriksaan di sidang pengadilan dilaksanakan tanpa kehadiran terdakwa sebagaimana diatur pada 79 Undang-Undang Nomor 31 Tahun 2004 tentang Perikanan.

Pada prinsipnya, zona ekonomi eksklusif berbeda dengan laut territorial, perairan kepulauan dan perairan pedalaman. Di Zona Ekonomi Eksklusif Negara pantai hanya mempunyai hak berdaulat atas kegiatan-kegiatan dan konservasi sumber daya alam hayati dan non hayati, sedangkan di laut territorial, perairan pedalaman dan perairan kepulauan Negara pantai mempunyai kedaulatan penuh.

5. Bertentangan dengan Pasal 104 Ayat (1) UndangUndang Nomor 31 Tahun 2004 Tentang Perikanan

Pasal 104 ayat (1) Undang-Undang Nomor 31 Tahun 2004 Tentang Perikanan menyatakan bahwa kapal ikan asing yang melakukan tindak pidana perikanan di ZEE Indonesia dapat dibebaskan dengan menyerahkan sejumlah uang jaminan oleh nahkoda, pemilik kapal atau perwakilan negaranya sesuai dengan harga kapal, alat perlengkapan kapal, dan hasil dari kegiatannya, ditambah besarnya jumlah denda maksimum.

Pembebasan kapal ikan asing tersebut seharusnya ditawarkan penangkap/penyidik kepada nakohda / pemilik kapal ikan atau perwakilan negaranya pada saat dimulainya penyidukan yaitu mengajukan permohonan penebusan guna pembebasan kapal ikannya kepada pengadilan perikanan karena merupakan haknya yang sudah diatur oleh pasal 73 Ayat (2) konvensi PBB Tahun 1983 tentang hukum laut (Unclos 1982) dan Pasal 15 Undang-Undang Nomor 5 Tahun 1983 tentang ZEE Indonesia serta pasal 104 Ayat (1) Undang-Undang Nomor 31 Tahun 2004 Tentang Perikanan yang menyatakan bahwa:

"Permohonan untuk membebaskan kapal dan/ atau orang yang ditangkap karena melakukan tindak pidana di wiulayah pengelolaan perikanan Republik Indonesia sebagaimana dimaksud dalam Pasal 5 ayat (1) huruf b (ZEE Indonesia), dapat dilakukan setiap waktu sebelum ada keputusan dari pengadilan perikanan dengan menyerahkan sejumlah uang jaminan yang layak, yang penetapannya dilakukan oleh pengadilan perikanan".

Penjelasan Pasal 104 Ayat (1) tersebut menyatakan: "Yang dimaksud dengan sejumlah uang jaminan yang layak, adalah penetapan besar uang jaminan yang ditentukan berdasarkan harga kapal, alat perlengkapan kapal dan hasil dari kegiatannya, ditambah besarnya jumlah denda maksimum"

Pasal 104Ayat (1) dan penjelasannya dan beberapa pasal lainnya masih tetap berlaku karena tidak dihapus oleh Undang-Undang Nomor 45 Tahun 2009 Tentang Perubahan Atas Undang-Undang Nomor 31 Tahun 2004 Tentang Perikanan. Berdasarkan Pasal 104 Ayat (1) dan Penjelasannya tersebut pembakaran dan/atau penenggelaman kalai ikan asing yang melakukan tindak pinana perikanan di ZEE Indonesia tidak boleh dilakukan. Dari ketentuan pasal 104 ayat (1) tersebut di atas dapat dijelaskan bahwa pembebasan kapal ikan asing yang melakukan tindak pidana perikanan di ZEE Indonesia dapat dilakukan dengan jaminan sejumlah uang.

\section{Belum Ada Putusan Pengadilan yang Berkekuatan Hukum Tetap (Inkracht)}

Dalam istilah hukum pidana, dalam penegakan hukum dinyatakan bahwa tidak ada suatu hukuman tanpa kesalahan yang sudah dijatuhkan/ divonis dalam putusan pengadilan yang berkekuatan hukum tetap. Demikian juga dengan azas Praduga Tidak Bersalah (presumption of innocence) dinyatakan bahwa setiap orang yang disangka, dituntut, dan dimajukan ke hadapan sidang pengadilan diasumsikan atau dianggap tidak bersalah sampai adanya putusan pengadilan yang telah memperoleh kekuatan hukum tetap (inkracht van gewijs.d.e).

Salah satu elemen penting dari negara hukum menuut Frederich Julius Stahl adalah adanya perlindungan hukum terhadap hak asasi manusia (HAM). Melakukan eksekusi tanpa proses hukum dan tidak dibawa ke persidangan termasuk belum mempunyai putusan pengadilan yang berkekuatan hukum tetap merupakan pelanggaran hukum. Pemerintah dalam hal ini KKP tidak menghormati pengadilan perikanan yang sudah diatur pada pasal 71 Undang-Undang Nomor 45 tentang Perikanan.

Berdasarkan penjelasan tersebut di atas, setiap orang termasuk nahkoda kapal ikan asing yang melakukan tindak pidana perikanan terutama di ZEE Indonesia harus diasumsikan/ dianggap tidak 
bersalah sampai adanya putusan pengadilan yang telah memperoleh kekuatan hukum tetap. Oleh karena itu, anggapan bahwa nahkoda kapal ikan karena tertangkap tangan sudah pasti bersalah sebelum ada putusan pengadilan adalah anggapan yang salah sehingga kapal ikan sebagai alat atau sarana yang diduga dipakai untuk melakukan tindak pidana perikanan belum boleh dibakar dan/atau ditenggelamkan sebelum ada putusan pengadilan tersebut.Dengan adanya putusan pengadilan berarti bahwa penyelesaian perkara tindak pidana perikanan di ZEE Indonesia sudah melalui proses hukum yang benar.

Apabila tindakan pembakaran dan/atau penenggelaman sudah dilakukan terhadap kapal ikan asing sebelum ada putusan pengadilan yang berkekuatan hukum tetap (eksekusi mendahului putusan/premature), tetapi pada kenyataannya putusan pengadilan memutuskan nahkoda kapal ikan asing tersebut tidak bersalah, putusan hakim tersebut harus dianggap benar (Res Judicata Pro Veritate Habetur) yang artinya putusan hakim dianggap benar, dimana putusan tersebut dijatuhkan dengan irah-irah " Demi Keadilan Berdasarkan Ketuhanan Yang Maha Esa”

\section{Norma Hukum Baru Agar Pembakaran dan/ atau Penenggelaman Kapal Ikan Asingt Tidak Menimbulkan Protes dan Gugatan Negara- Negara Yang Kapal Ikannya Dibakar dan/atau Ditenggelamkan.}

Dalam penegakan hukum berupa pembakaran dan/atau penenggelaman terhadap kapal ikan asing yang melakukan tindak pidana perikanan di ZEE Indonesia, negara-negara yang kapalnya ditangkap ada yang melakukan protes karena kapal ikannya yang ditangkap tersebut dibakar dan/atau ditenggelamkan oleh pemerintah Indonesia. Untuk mencegah agar jangan sampai terjadi protes lagi, maka perlu ditemukan norma hukum baru untuk memback up penegakan hukum tersebut. Tindakan khusus berupa pembakaran dan/atau penenggelaman kapal ikan asing yang melakukan penangkapan ikan illegal di wilayah ZEE Indonesia dilakukan karena adanya pasal 69 ayat (1), (4) dan pasal 76A UndangUndang Nomor 45 Tahun 2009 tentang Perikanan. Dalam undang-undang Perikanan yang sebelumnya yaitu Undang-Undang Nomor 9 Tahun 1985 dan Undang-Undang Nomor 31 Tahun 2004 tidak ada ketentuan yang mengatur tentang tindakan khusus berupa pembakaran dan/atau penenggelaman kapal ikan asing tersebut yang melakukan tindak pidana perikanan di ZEE Indonesia.

Penyelesaian hukum terhadap kapal ikan asing yang melakukan tindak pidana perikanan di ZEE Indonesia yang dilakukan Pemerintah Indonesia beberapa tahun terakhir ini dengan menggunakan dasar hukum pasal 69 ayat (1), (4) dan Pasal 76A Undang-Undang Nomor 45 Tahun 2009 tentang Perikanan juga berdasarkan persetujuan Ketua Pengadilan Negeri adalah tidak sesuai dengan Hukum Internasional dalam hal ini pasal 73 ayat (2) Konvensi PBB Tentang Hukum Laut tahun 1982 dan bertentangan dengan Hukum Nasional yaitu pasal 15 Undang-.Undang Nomor 5 Tahun 1983 tentang Zona Ekonomi Eksklusif Indonesi serta pasal 104 ayat

(1) Undang-Undang Nomor 31 Tahun 2004 Tentang Perikanan.

Dalam hal kapal ikan asing yang ditangkap oleh kapal patroli Indonesia karena melakukan tindak pidana perikanan di ZEE Indonesia, Negara penangkap wajib memberitahukan penangkapan atau penahanan kapal asing, Negara pantai harus segera memberitahukan kepada Negara bendera melalui saluran yang tepat mengenai tindakan yang diambil dan mengenai setiap hukuman yang kemudian dijatuhkan. Berdasarkan pemberitahuan tersebut, Negara yang kapal ikannya di tangkap atau ditahan dapat melakukan berbagai upaya hukum guna menebus kapal ikannya dengan uang jaminan sesuai pasal 73 ayat (2) Unclos 1982.

Dalam penyelesaian hukum terhadap kapal ikan asing yang melakukan tindak pidana perikanan di ZEE Indonesia untuk menghindari terjadinya protes, gugatan hukum dan/atau sengketa antara Indonesia dengan negara-negara yang kapal ikannya dibakar dan/ atau ditenggelamkan, Dalam melakukan penegakan hukum tindak pidana perikanan, harmonisasi antara hukum nasional dengan hukum laut internasional terutama saat pembuatan undang-undang yang terkait dengan ZEE Indonesia dan perikanan agar mengacu kepada Konvensi PBB Tahun 1982 tentang hukum laut yang sudah diratifikasi dengan hukum nasional yaitu Undang-Undang Nomor 17 Tahun 1985 yang selanjutnya ditindaklanjuti dengan penegakan hukumnya, oleh karena itu harus ada norma hukum baru yang diterapkan yang sesuai dengan teori berdaulat yaitu berdasarkan hukum laut internasional/ Konvensi PBB tentang Hukum Laut 1982 (Unclos 1982) dan hukum nasional yaitu Undang-Undang Nomor 5 Tahun 1983 tentang ZEE Indonesia serta pasal 104 ayat (1) Undang-Undang Nomor 31 Tahun 


\section{Tentang Perikanan.}

Norma hukum baru yang bisa melahirkan penemuan hukum karena dalam praktek tidak jarang dijumpai ada peristiwa yang belum diatur dalam perundang-undangan atau meskipun sudah diatur tetapi tidak lengkap dan tidak jelas. Tidak ada hukum atau perundang-undangan yang lengkap selengkaplengkapnya atau jelas sejelas-jelasnya. Meskipun ada beberapa hal yang sudah diatur dalam hukum namun belum menyentuh substansi yang diharapkan Unclos 1982 yang sudah diwejawantahkan dan diratifikasi negara Indonesia dalam bentuk hukum nasional Undang-Undang Nomor 17 Tahun 1985

Norma hukum baru tersebut dapat dibagi menjadi 2 (dua) cara yaitu kapal ikan asing ditebus/dibebaskan oleh nahkoda/pemilik dan perwakilan negaranya atau tidak akan ditebus/ dibebaskan oleh nahkoda/ pemilik dan perwakilan negaranya sebagai berikut

1. Apabila Kapal Ikan Asing Akan Ditebus/Dibebaskan oleh Nahkoda/Pemilik atau Perwakilan Negaranya.

Berdasarkan pasal 73 ayat (2) Unclos 1982 dan pasal 15 Undang-Undang Nomor 5 Tahun 1983 tentang ZEE Indonesia, serta pasal 104 Ayat (1) Undang-Undang Nomor 31 Tahun 2004 Tentang Perikanan, kapal ikan asing yang melakukan tindak pidana perikanan di ZEE Indonesia dapat ditebus/ dibebaskan dengan menyerahkan sejumlah uang jaminan oleh nahkoda, pemilik kapal atau perwakilan negaranya sesuai dengan harga kapal, alat perlengkapan kapal, dan hasil dari kegiatannya, ditambah besarnya jumlah denda maksimum.

Pembebasan dengan cara penebusan dengan sejumlah uang tersebut tidak terlepas dari latar belakang adanya suatu zona ekonomi eksklusif adalah untuk peningkatan kesejaterahan bangsa dengan memanfaatkan sumber daya alam yang tersedia baik hayati maupun non hayati. Dengan jaminan sejumlah uang yang masuk ke kas negara, diharapkan dapat meningkatkan kesejaterahan bangsa terutama kesejaterahan nelayan. Penebusan/ pembebasan kapal ikan asing tersebut seharusnya disampaikan penangkap/penyidik kepada nakohda /pemilik kapal ikan atau perwakilan negaranya agar mengajukan permohonan penebusan kepada pengadilan perikanan/ negeri guna pembebasan kapal ikannya karena merupakan haknya yang sudah diatur oleh pasal 73 Ayat (2) Unclos 1982 dan Pasal 15 Undang-Undang Nomor 5 Tahun 1983 tentang ZEE Indonesia serta pasal 104 ayat (1) Undang-Undang Nomor 31 Tahun
2004 Tentang Perikanan yang menyatakan:

"Permohonan untuk membebaskan kapal dan/ atau orang yang ditangkap karena melakukan tindak pidana di wiulayah pengelolaan perikanan Republik Indonesia sebagaimana dimaksud dalam Pasal 5 ayat (1) huruf b Undang-Undang Nomor 5 Tahun 1982 tentang ZEE Indonesia, dapat dilakukan setiap waktu sebelum ada keputusan dari pengadilan perikanan dengan menyerahkan sejumlah uang jaminan yanglayak, yang penetapannya dilakukan oleh pengadilan perikanan".

Permohonan untuk membebaskan kapal ikan dengan sejumlah uang jaminan tersebut diajukan ke pengadilan perikanan, yang sampai sekarang baru dibentuk di beberapa kota saja atau pengadilan negeri apabila tidak ada pengadilan perikanan.Penjelasan Pasal 104 Ayat (1) menyatakan:"Yang dimaksud dengan sejumlah uang jaminan yang layak, adalah penetapan besar uang jaminan yang ditentukan berdasarkan harga kapal, alat perlengkapan kapal dan hasil dari kegiatannya, ditambah besarnya jumlah denda maksimum"

Berdasarkan Pasal 104 Ayat (1) dan Penjelasannya tersebut, pengadilan perikanan harus segera melakukan koordinasi dengan instansi terkait guna mengeluarkan penetapannya akan sejumlah uang sebagai jaminan untuk pembebasan kapal ikan asing yang melakukan tindak pidana perikanan di ZEE Indonesia.

Hakimpengadilanperikanansebelummenetapkan sejumlah uang jaminan, permohonan pembebasan kapal ikan harus terlebih dahulu diajukan kepada hakimpengadilanperikanantersebutdengantembusan penyidik dan jaksa penuntut umum. Permohonan untuk membebaskan kapal dapat diajukan sendiri oleh yang nahkoda/pemilik atau perwakilan negaranya atau melalui penasihat hukumnya atau perwakilan negaranya..

Terhadap hal tersebut di atas, tersangka/ terdakwa dapat mengajukan permohonan pembebasan dirinya dan barang-barang yang disita oleh petugas termasuk kapal ikannya. Dasar hukumnya selain pasal 15 Undang-Undang Nomor 5 Tahun 1983 tentang juga berdasarkanpasal 104 ayat(1) Undang-Undang Nomor 31 Tahun 2004 tentang Perikanan. Permohonan dapat diajukan sendiri oleh yang bersangkutan atau melalui penasihat hukumnya atau perwakilan negaranya. Harga kapal dan alat-alat perlengkapan kapal dan hasil kegiatannya, ditambah besarnya jumlah denda maksimum sebagaimana disebutkan pada penjelasan 
pasal 15 huruf b) Undang-Undang Nomor 5 Tahun 1983 Tentang ZEE Indonesia dan penjelasan pasal 104 Ayat (1) Undang-Undang Nomor 31 Tahun 2004 Tentang Perikanan harus ditentukan oleh masingmasing instansi yang berkompeten dan berwenang sesuai dengan keahliannya. Taksiran harga harus disesuaikan dengan indeks harga yang berlaku resmi di negara Indonesia yang dikeluarkan pemerintah Indonesia.

Untuk kapal dan alat perlengkapan kapal, taksiran harganya (taksasi) dilakukan oleh staf ahli lembaga yang berwenang yaitu staf Direktorat Jenderal Perhubungan Laut Kementerian Perhubungan. Dalam menentukan nilai/harga sebuah kapal harus betulbetul teliti, harga sebauh kapal yang bahannya terbuat dari besi lebih mahal dibandingkan dengan sebuah kapal yang terbuat dari kayu. Ukuran besar kecilnya sebuah kapal berpengaruh terhadap harga sebuah kapal, semakin besar ukuran sebuah kapal tentunya semakin mahal harganya. Perlengkapan kapal yang cangggih dan modern juga berpengaruh akan harga sebuah kapal. Staf Direktorat Jenderal Perhubungan Laut Kementerian Perhubungan dalam menentukan nilai/harga perlengkapan kapal harus meneliti apakah perlengkapan kapal dalam kondisi baik, rusak atau rusak berat. Apabila perlengkapan kapalnya modern/ canggih dan berapa banyak jumlahnya, dan bagaimana kondisinya. Apabila perlengkapannya canggih/modern, banyak jumlahnya dengan kondisi baik maka harganya tentunya lebih mahal.

Untuk hasil dari kegiatannya yang biasanya berupa ikan, taksiran harganya ditentukan oleh lembaga lelang Negara bekerjasama dengan KKP. Jenis-jenis ikan tertentu misalnya ikan kakap, tuna, cumi-cumi, udang tentunya harganya lebih mahal. Banyaknya ikan hasil tangkapan juga sangat berpengaruh akan uang jaminan yang akan diberikan oleh nahkoda/pemilik kapal atau perwakilan negaranya.Sedangkan besarnya jumlah denda maksimum untuk tindak pidana yang terjadi di ZEE Indonesia sebagaimana telah ditentukan pada pasal 16 angka (1) UndangUndang Nomor 5 Tahun 1983 tentang adalah $\mathrm{Rp} 225.000 .000$, (dua ratus dua puluh lima juta rupiah)

Berdasarkan taksiran yang telah dijelaskan tersebut di atas, sejumlah uang yang layak sebagai uang jaminan yang akan diberikan oleh nahkoda/ pemilik kapal atau perwakilan negaranya tentunya akan sangat banyak. Jumlahjaminan uang yang banyak tersebut apabila dapat dipenuhi oleh nahkoda/pemilik kapal ataupun perwakilan negaranya maka akan merupakan pemasukan bagi kas negara dari sektor perikanan di ZEE Indonesia Perlu diingat bahwa ZEE adalah suatu kawasan yang dimungkinkan sebagai penghasil devisa negara untuk peningkatan ekonomi negara pantai demi kesejaterahan rakyatnya.

Pembebasan kapal tersebut juga harus dilengkapi dengan penetapan pengadilan perikanan guna terpenuhinya kepastian hukum. Setelah mempunyai/ memiliki penetapan pengadilan perikanan, bagaimana dengan pelaksanaannya, apakah jika pembebasan orang dan kapal jaminannya hanya satu atau jaminannya harus dua sesuai dengan jumlah pembebasan yang diminta (kapal dan/atau orang). Karena ketentuan dalam pasal 73 ayat (2) Unclos 1982 tersebut di atas merupakan 1 (satu) pasal sendiri nahkoda dan kapalnya maka pembebasannya merupakan satu kesatuan (satu paket), kapal ikan asing dapat berlayar kembali setelah membayar uang jaminan dan tentunya dengan dinahkodai oleh nahkodanyasendirisambilmembawapulanganakbuah kapalnya (ABK). Agar penanganan kapal ikan asing yang nyata-nyata memang memerlukan penanganan segera supaya tidak banyak mengeluarkan biaya dalam perawatan dan pengamanan kapal tangkapan tersebut, pangkalan/pelabuhan menjadi tidak penuh, semrawut/ kumuh karena menampung banyak kapal ikan yang semakin lama semakin rusak, maka sudah sewajarnyalah permohonan penebusan kapal ikan asing karena melakukan tindak pidana perikanan di ZEE Indonesia dikabulkan atau diijinkan.

Dalam proses pembebasan/ penebusan kapal ikannya, diberikan jangka waktu paling lama selama 30 hari yaitu waktu selama keseluruhan penahanan tersangka oleh penyidik yang terdiri dari penahanan paling lama 20 hari dan dapat diperpanjang 10 hari lagi sebagaimana diatur pada pasal 73B ayat (2) dan ayat (3) UndangUndang Nomor 45 Tahun 2009 tentang Perikanan.Salah satu kewajiban negara pantai (negara Indonesia) yang tersirat dalam Bab V Konvensi Hukum Laut PBB 1982 yang mengatur tentang ketentuan Zona Ekonomi Eksklusif adalah bahwa negara penangkap harus melepaskan dengan segera kapal dan anak buah kapal yang ditangkap setelah memberikan uang jaminan yang layak atau bentuk jaminan lainnya (pasal 73 ayat 2). Apabila nahkoda dan crew sudah memberikan uang jaminan untuk pembebasan menunggu putusan pengadilan baru dapat bebas pulang ke negaranya, hal tersebut tentunya akan ditolak oleh mereka karena mereka sudah memberikan/ mengeluarkan sejumlah uang, atau mereka akan meminta suatu jaminan bahwa 
mereka dan kapalnya akan bisa dipulangkan.

Berdasarkan penjelasan Undang-Undang Nomor 5 Tahun 1983 dinyatakan bahwa ZEE merupakan rezim hukum laut internasional. Oleh karena itu, kedaulatan negara Indonesia diwujudkan dalam hukum pidananya yang dapat diterapkan di ZEE Indonesia hanya hukum pidana yang menyangkut pelanggaran terhadap eksplorasi dan eksploitasi sumber daya alam hayati yang tidak bertentangan dengan Konvensi PBB Tentang Hukum Laut Tahun 1982. Negara Indonesia tidak boleh menerapkan sepenuhnya hukum nasionalnya di ZEEnya yang tidak sesuai dengan hukum laut internasional. Berdasarkan pembahasan tersebut di atas, kapal ikan asing yang melakukan tindak pidana perikanan di ZEE Indonesia dapat ditebus/dibebaskan setelah ada uang jaminan yang layak oleh nahkoda/pemilik kapal atau perwakilan. Indonesia sebagai negara pantai, melalui pengadilan negeri/pengadilan perikanan adalah yang mempunyai kedaulatan untuk memberikan persetujuan akan penebusan dengan uang jaminan tersebut.

2 Kapal Ikannya Tidak Akan Dibebaskan/Ditebus oleh Nakhoda/ Pemilik Kapal atau Perwakilan Negara Kapal.

Apabila nahkoda/ pemilik dan perwakilan negaranya tidak akan menebus/membebaskan kapal ikannya yang melakukan tindak pidana perikanan di ZEE Indonesia maka norma hukum baru yang akan ditemukan adalah berupa" mekanisme yang ditempuh dalam melakukan tindakan khusus berupa pembakaran dan/atau penenggelaman kapal ikan asing yang melkukan tindak pidana perikanan di ZEE Indonesia " sebagai berikut:

Pada saat kapal ikan suatu negara ditangkap dan dilanjutkan dengan proses hukum, selanjutnya saat dimulainya penyidikan, penangkap/ Penyidik harus segera memberitahukan (Notice) kepada perwakilan negaranya bahwa kapal ikannya/ nelayan warga negaranya ditangkap dan akan menjalani proses hukum, Penyidik juga menawarkan kepada nahkoda/ pemilik atau perwakilan negaranya apakah kapal ikannya akan dibebaskan/ ditebus atau tidak. Apabila tidak akan dibebaskan/ ditebus, karena tidak mampu atau tidak mau memberikan sejumlah uang jaminan, maka mereka harus mau menerima hukuman (vonis) terakhir yang akan dijatuhkan oleh pengadilan Republik Indonesia, baik hukuman pokok maupun hukuman tambahan.

Apabila ada hukuman tambahan, salah satunya adalah perampasan barang tertentu, bisa saja pemusnahan barang bukti berupa pembakaran dan/ atau penenggelaman kapal ikannya yang melakukan tindak pidana perikanan di ZEE Indonesia tersebut. Apabila sudah ada kepastian bahwa kapal ikannya tidak akan dibebaskan/ ditebus, maka penyidik segera membuat surat pernyataan yang ditandatangani oleh nakhoda/ pemiliknya atau perwakilan negaranya yang menyatakan "Persetujuan Pemusnahan terhadap Kapal Ikannya berupa tindakan Pembakaran dan/atau Penenggelaman karena melakukan Tindak Pidana Perikanan di ZEE Indonesia:"

Surat pernyataan tersebut dimaksudkan apabila suatu saat nakhoda/ pemilik kapal ikan atau perwakilan negaranya atau ada pihak-pihak lain yang memprotes bahkan menggugat negara/ pemerintah Republik Indonesia atas pemusnahaan barang bukti berupa Pembakaran dan/atau Penenggelaman kapal ikannya karena melakukan Tindak Pidana Perikanan di ZEE Indonesia, maka negara/ pemerintah Republik Indonesia bisa menunjukkan kembali surat pernyataan tersebut dan putusan pengadilan kepada pihak-pihak yang memprotes/ menggugat. Surat pernyataan tersebut dilampirkan dalam berkas perkara atau merupakan bagian dari berkas perkara. Surat pernyataan tersebut juga dijadikan bahan pertimbangan hakim untuk memutuskan perkara. Proses hukum terhadap nahkoda kapal tangkapan tetap berjalan sampai dengan proses persidangan di pengadilan. Apabila putusan pengadilan yang berkekuatan hukum tetap sudah dijatuhkan (inkracht) dengan hukuman tambahan pemusnahan barang bukti berupa kapal, maka pemusnahaan kapal ikan dengan cara dibakar dan/atau ditenggelamankan baru dapat dilakukan ( dieksekusi).

Meskipun nahkoda, pemilik kapal atau perwakilan negaranya sudah membuat pernyataan bersediakapal ikannya dimusnahkan atau tidak mau membebaskan dengan cara menebus kapal ikannya, pelaksanaan pembakaran tidak boleh dilakukan sebelum ada putusanpengadilanyangberkekuatanhukumtetapatau pemusnahan barang bukti tidak boleh dilaksanakan pada saat proses hukum sedang berjalan artinya eksekusi tidak boleh premature, mendahului putusan pengadilan, walaupun instansi yang akan melakukan pembakaran dan/atau penenggelaman sangat yakin bahwa putusan pengadilan akan memutuskan nahkoda bersalah dan dengan hukuman tambahan 
kapal ikan sebagai barang bukti dimusnahkan, tetap juga pelaksanaan pemusnahan harus menunggu putusan (vonis) pengadilan yang berkekuatan hukum tetap.

Pemusnahaan barang bukti berupa pembakaran dan/ atau peneggelaman kapal juga tidak boleh dilakukan kalau pengadilan tidak menjatuhkan hukuman tambahan berupa "pemusnahan barang bukti”. Oleh karena itu, tindakan pembakaran dan/ atau penenggelaman kapal (eksekusi) baru boleh dilaksanakan setelah ada putusan pengadilan (vonis) yang sudah berkekuatan hukum tetap tersebut dengan hukuman tambahan "pemusnahan barang bukti" dan juga dalam berkas perkara sebelumnya sudah ada surat pernyataan nahkoda/pemilik atau perwakilan negaranya tentang "Persetujuan Pemusnahan terhadap barang bukti kapal ikannya berupa tindakan Pembakaran dan/atau Penenggelaman karena melakukan Tindak Pidana Perikanan di ZEE Indonesia.

Penegakan hukum berupa eksekusi terhadap barang baukti/ sarana untuk melakukan tindaka pidana di laut setelah putusan pengadilan (inkracht) adalah satu cara mencegah terjadinya kegagalan hukum karena upaya hukum sudah maksimal dilakukan, tetapi apabila belum inkracht kapal sudah dimusnahkan, nahkoda/ pemilik kapal atau perwakilan negaranya masih mempunyai hak melakukan upaya hukum.

Demi mewujudkan hukum yang pasti dan berkeadilan, eksekutor yang melaksanakan putusan pengadilan adalah Jaksa Penuntut Umum karena berdasarkan pasal 30 Ayat (1) Undang-Undang Nomor 16 Tahun 2004 Tentang Kejaksaan Republik Indonesia dinyatakan:

Bahwa di bidang pidana, kejaksaan mempunyai tugas dan wewenang melaksanakan penetapan hakim dan putusan pengadilan yang telah memperoleh kekuatan hukum tetap.

Demikian juga yang telah diatur dalam hukum acara pidana, berdasarkan pasal 13 Undang-Undang Nomor 8 Tahun 1981 Tentang KitabUndang-Undang Hukum Acara Pidana (KUHAP) perihal Penuntut Umum juga dinyatakan:

Bahwa Penuntut umum adalah jaksa yang diberi wewenang oleh undang-undang ini untuk melakukan penuntutan dan melaksanakan penetapan hakim.

Berdasarkan pasal 30 Ayat (1) huruf b UndangUndang Nomor 16 Tahun 2004 Tentang Kejaksaan RepublikIndonesiamentatakankewenangankejaksaan menyatakan melaksanakan penetapan hakim dan putusan pengadilan yang telah mempunyai kekuatan hukum tetap juga pasal 13 Undang-Undang Nomor 8 Tahun 1981 Tentang Kitab Undang-Undang Hukum Acara Pidana (KUHAP) perihal Penuntut Umum tersebut di atas eksekusi pemusnahan barang bukti harus dilaksanakan oleh pihak Kejaksaan sebagai penuntut umum, bukan Kementerian Kelautan dan Perikanan apalagi aparat TNI/Polri. Kalaupun ada partisipasi aparat TNI/Polri itu hanyalah sifatnya TNI sebagai pengamanan di laut dan Polri sebagai tenaga pelaksana pemusnahan barang bukti, pihak Kejaksaan bukan sebagai saksi, tetapi sebagai pelaksana penetapan hakim. Wewenang dan Tanggung jawab pembakaran dan/atau penenggelaman kapal ikan ada pada pihak Kejaksaan sebagai eksekutor pemusnahan barang bukti pembakaran dan/atau penenggelaman kapal.

Pada pasal 46 Ayat (2) KUHAP dinyatakan: "Apabila perkara sudah diputus, maka benda yang dikenakan penyitaan dikembalikan kepada orang atau kepada mereka yang disebut dalam putusan tersebut, kecuali jika menurut putusan hakim benda itu dirampas untuk negara, untuk dimusnahkan atau untuk dirusakkan sampai tidak dapat dipergunakan lagi atau jika benda tersebut masih diperlukan sebagai barang bukti dalam perkara lain."

Berdasarkan ketentuan tersebut di atas, jelas dinyatakan bahwa pemusnahan barang bukti baik kapal maupun benda lain, perkaranya harus sudah diputus pengadilan terlebih dahulu, pemusnahan tidak boleh mendahului putusan pengadilan, tidak boleh semena-mena, sejauh mungkin diperhatikan segi kemanusiaan karena barang bukti terutama kapal adalah sebagai sarana untuk mencari sumber kehidupan nelayan meskipun nelayan-nelayan tersebut nelayan asing. Pemusnahan barang bukti/ benda yang digunakan sebagai sarana/alat untuk melakukan tindak pidana perikanan, sedapat mungkin dihindari tuntutan/gugatan dari berbagai pihak, baik dari nahkoda/ pemilik barang bukti maupun dari masyarakat yang dirugikan. Oleh karena itu, sejauh mungkin dipatuhi peraturan perundang-undang yang mengatur pemusnahan barang bukti baik hukum nasional (KUHAP) maupun hukum internasional.

\section{Kesimpulan dan Saran}

Negara-negara yang kapal ikannya ditangkap Indonesiamenentangtindakankhususpembakaran dan/atau penenggelaman kapal ikannya yang melakukan tindak pidana perikanan di ZEE 
Indonesia karena (a) bertentangan Konvensi PBB Tahun 1982 tentang Hukum Laut (Unclos 1982) yaitu pasal 73 ayat (2), pasal 194, 3) pasal 309; (b) bertentangan dengan pasal 15 UndangUndang Nomor 5 Tahun 1983 tentang Zona Ekonomi Eksklusif Indonesia, (c) bertentangan denga pasal 104 ayat (1) Undang-UndangNomor 31 Tahun 2004 tentang perikanan, dan (d) belum ada putusan pengadilan yang berkekuatan hukum tetap (inkracht van gewijs.d.e).

Norma hukum baru agar pembakaran dan/atau penenggelaman kapal ikan asing yang melakukan tindak pidana perikanan di ZEE Indonesia tidak menimbulkan protes dan gugatan adalah sebagai berikut: (a) apabila kapal ikan asing yang melakukan tindak pidana perikanan di ZEE Indonesia tersebut akan ditebus/ dibebaskan maka mekanisme yang ditempuh adalah dengan menyerahkan sejumlah uang jaminan oleh nahkoda, pemilik kapal atau perwakilan negaranya ke kas negara sesuai dengan (i) harga kapal, alat perlengkapan kapal yang taksiran harganya dihitung oleh staf Direktorat Navigasi Direktorat Jenderal Perhubunga Laut; (ii) hasil dari kegiatannya (ikan) yang dilelang yang pelelangannya ditangani oleh Kementerian Kelautan dan Perikan dan Badan Lelang Negara: (iii) jumlah denda maksimum sebesar $\mathrm{Rp}$ 225.000.000 (dua ratus dua puluh lima juata rupiah), walaupun sejumlah uang jaminan oleh nahkoda, pemilik kapal atau perwakilan negaranya sudah diserahkan, tetapi penetapan pembebasan kapal ikan tersebut merupakan kewenangan pengadilan perikanan atau pengadilan negeri apabila di daerah tersebut tidak ada pengadilan perikanan, kewenangan pengadilan tersebut merupakan kedaulatan negara Indonesia. (b) Pembakaran dan/atau penenggelaman kapal ikan asing berupa dapat dilakukan apabila:

(i) kapal ikan asing tersebut tidak ditebus/

tidak dibebaskan oleh nahkoda/pemilik atau perwakilan negaranya, maka mekanisme yang ditempuh adalah nahkoda, pemilik kapal atau perwakilan negaranya tersebut harus membuat surat pernyataan yang merupakan bagian dari berkas perkara yang menyatakan bahwa kapal tidak akan ditebus dan bersedia dimusnahkan dan (ii) pengadilan menolak permohonan penebusan/ pembebasan kapalk ikan asing tersebut.

Agar pemusnahan barang bukti berupa pembakaran dan/atau penenggelaman kapal ikan asing yang melakukan tindak pidana perikanan di ZEE Indonesia dilakukan tidak menimbulkan protes dan gugatan maka pemusnahan tersebut harus sesuai/ tidak bertentangan dengan pasal 73 ayat (2), pasal 194, pasal 309 Konvensi PBB tentang Hukum Laut Tahun 1982 (Unclos 1982) dan hukum nasional Indonesia khususnya pasal 15 Undang-Undang Nomor 5 Tahun 1983 tentang , pasal 104 ayat (1) Undang-Undang Nomor 31 Tahun 2004 tentang Perikanan serta harus berdasarkan putusan pengadilan yang telah berkekuatan hukum tetap (Inkracht van gewijs.d.e). Agar Pemerintah dan Dewan Perwakilan Rakyat membuat peraturan perundang-undangan tentang perikanan yang baru yang juga mengatur tentang mekanisme pembebasan dan pemusnahan kapal yang ditangkap sesuai dengan konsepsi hukum yang disebutkan di atas sehingga pembakaran dan/atau penenggelaman kapal ikan asing tersebut tidak bertentangan dengan hukum internasional dan hukum nasional guna menghormati ratifikasi Konvensi PBB tentang Hukum Laut 1982 dan menghindari negara-negara yang kapal ikannya di tangkap karena melakukan tindak pidana perikanan di ZEE Indonesia, diadili di pengadilan internasional hukum laut (International Tribunal Law Of The Sea /ITLOS). 


\section{Daftar Pustaka}

\section{Buku}

A. Hamzah, Laut, Teritorial dan Perairan Indonesia, Cetakan pertama, Penerbit: Akademika Pressindo, Jakarta 1984.

Akhmad Solihin, Politik Hukum Kelautan \& Perikanan, Isu, Permasalahan, dan Telaah Kritis Kebijakan, Cetakan I, Penerbit: Nuansa Aulia, Bogor 2010.

Arif Johan Tunggal, Pokok-Pokok Hukum Laut, Penerbit: Havarindo, Jakarta 2010.

Bambang Waluyo, Penegakan Hukum di Indonesia, Cetakan pertama, Penerbit: Sinar Grafika, Jakarta 2016.

Boert Mauna, Hukum Internasional, Pengertian Peranan dan Fungsi Dalam Era Dinamika Global, Edisi ke-2, Cetakan kw-1, Penerbit: P.T. Alumni, Bandung 2005.

Chairul Anwar, Hukum Internasional, Horizon Baru Hukum Laut Internasional, Konvensi Hukum Laut 1982, Cetakan, Penerbit: Djambatan, Jakarta 1989.

Deni Bram, Hukum Lingkungan Internasional, Penerapan Prinsip Tanggung Jawab Negara, Cetakan 1, Penerbit: Cyintia Press Jakarta 2008.

Didik Mohamad Sodik, Hukum Laut Internasional dan Pengaturannya di Indonesia, cetakan Kesatu, Refika Aditama, Bandung September 2011.

Djoko Tribawono, Hukum Perikanan Indonesia, cetakan Ke II, Penerbit: PT Citra Adityia Bakti Bandung 2013.

Etty R. Agoes, Konvensi Hukum Laut 1982, Masalah Pengaturan Hak Lintas Kapal Asing, Cetakan pertama, Penerbit: Abardin, Bandung 1991.

FX. Adji Samekto, Negara dalam dimensi Hukum Internasional, Cetakan Ke I, Penerbit: PTcITRA Aditya Bakti, Bandung 2009.

Gatot Supramono, Hukum Acara Pidana dan Hukum Pidana di Bidang Perikanan, cetakan pertama, PT Rienaka Cipta, Jakarta juni 2011.

Hasjim Djalal, Perjuangan Indonesia Di Bidang Hukum Laut, Cetakan pertama, Penerbit: Binacipta, Jakarta 1979

Hikmahanto Juwana, Hukum Internasional Dalam Perspektif Indonesia Sebagai Negara Berkembang, Cetakan pertama, Penerbit: PT Yarsif Watampone, Jakarta 2010. 
H. Supriadi dan Alimuddin, Hukum Perikanan Indonesia, cetakan pertama, Penerbit: Sinar Grafika, Jakarta, April 2011.

Huala Adolf, Aspek-Aspek Negara Dalam Hukum Internasional, Cetakan ketiga, Penerbit: PT RajagRafindo Persada, Jakarta 2002.

Ida Kurnia, Kedudukan Negara-Negara pada Zona Ekonomi Eksklusif, cetakan 1, Diadit Media, Jakarta Mei 2007.

I Made Pasek Diantha, ZEE Indonesia, cetakan-1, Penerbit: CV Mandar Maju, Bandung 2002.

J.G Starke, Pengantar Hukum Internasional, Edisi kesepuluh jilid 1, Cetakan kedua belas, Penerbit: Sinar Grafika, Jakarta 2014.

J.G Starke, Pengantar Hukum Internasional, Edisi kesepuluh jilid 2, Cetakan keenam, Penerbit: Sinar Grafika, Jakarta 2007.

Marhaeni Ria Siombo, Hukum Perikanan Nasional dan Internasional, cetakan Pertama, Gramedia Pustaka, Jakarta 2010.

Mochtar Kusumaatmadja , Perkembangan Hukum Laut Indonesia Dewasa Ini, Cetakan pertama, Penerbit: Bina Cipta, P.T Alumni, Bandung 1975. Bandung 2015.

M. Karjadi dan R. Soesilo, Kitab Undang-Undang Hukum Acara Pidana dengan penjelasan dan komentar, Penerbit: Karya Nusantara, Bandung 1983.

—, Hak Asasi Tersangka Pidana, cetakan ke-1. Penerbit Kencana Prenadamedia Group. Jakarta 2015.

Nunung Mahmuda, Illegal Fishing, Pertanggungjawaban Pidana Korporasi di Wilayah Perairan Indonesia, Cetakan pertama, Penerbit: Sinar Grafika, Jakarta 2015.

Nur Yanto, Memahami Hukum Laut Indonesia, Penerbit: Mitra Wacana Media, Jakarta 2014.

R. Soesilo, Kitab Undang-Undang Hukum Pidana (KUHP) Serta Komentar-Komentarnya Lengkap Pasal demi Pasal, Cetak ulang, Penerbit: Politeia, Bogor 1995

Sahono Soebroto, Sunardi, Wahyono SK, Konvensi PBB Tentang Hukum Laut, Sebuah Tinjauan, cetakan pertama PT Jaya Pirusa, Jakarta, 1983.

Satjipto Rahardjo, Ilmu Hukum, cetakan ke VIII, Penerbit: PT Citra Aditya Bakti. Bandung 2014.

Soerjono Soekanto, Faktor-Faktor yang 
mempengaruhi Penegakan

Hukum,cetakan1,-9, Penerbit:

RajaGrafindo Persada, Jakarta 2010.

\section{Perundang-Undangan/ Konvensi/Kamus}

Konvensi PBB tenatang Hukum Laut 1982

(Unclos 1982).

Kitab Undang-Undang Hukum Pidana

(KUHP). Undang-Undang Nomor 8 Tahun

1981 tentang

KUHAP.

Undang-Undang Nomor 5 Tahun 1983

tentang ZEE Indonesia.

Undang-Undang Nomor 17 Tahun 1985 tentang

Ratifikasi UNCLOS 1982.

Undang-Undang Nomor 16 Tahun 2004

Tentang Kejaksaan RI.

Undang-Undang Nomor 31 Tahun 2004

tentang Perikanan

Undang-Undang Nomor 32 Tahun 2009

tentang Perlindungan dan Pengelolaan

Lingkungan Hidup.

Undang-Undang RI Nomor 45 Tahun 2009

tentang Perubahan Undang-. Undang

Nomor 31 Tahun 2004 tentang Perikanan

Undang-Undang Nomor 12 Tahun 2011 tentang Pembentukan Peraturan Perundang-Undangan. 